\title{
Pharmacological investigation of Thespesea populnea bark extract for analgesic activity
}

\author{
Jayakumar J. K.* \\ Department of Pharmacology, Sambram Institute of Medical Sciences and Research, Kolar Gold Fields, Karnataka, \\ India
}

Received: 12 October 2020

Accepted: 21 December 2020

\author{
*Correspondence: \\ Dr. Jayakumar J. K., \\ Email: drjkshapur@gmail.com
}

Copyright: (C) the author(s), publisher and licensee Medip Academy. This is an open-access article distributed under the terms of the Creative Commons Attribution Non-Commercial License, which permits unrestricted non-commercial use, distribution, and reproduction in any medium, provided the original work is properly cited.

\begin{abstract}
Background: Pain is an unpleasant and distressing common problem with profound impact on individuals and society. Existing treatment modalities used for pain management are either less effective or exhibits several side effects. The aim of current study is to investigate the analgesic activity of stem bark extract of Thespesea populnea for pain management.

Methods: Thirty Swiss albino were divided into five groups including control, standard and three tests groups (different doses of Thespesea populnea bark extract). Groups were investigated for analgesic activity using hot plate induced paw withdrawal, acetic acid induced writhing and formalin induced paw licking models.

Results: Findings of hot plate model revealed that, percent increase in reflex latency of paw licking response in mice for test drug $(10 \mathrm{mg} / \mathrm{kg})$, attained peak effect of $136 \%$ at 180 minutes, whereas for standard pentazocine peak effect of $125 \%$ was attained at 180 minutes. In acetic acid model, the maximum percent inhibition in number of writhings for the test drug $(30 \mathrm{mg} / \mathrm{kg})$ was $68 \%$ and for standard diclofenac, it was $80 \%$. In formalin model, percent inhibition in licking response in early and late phases for test drug $(30 \mathrm{mg} / \mathrm{kg})$ were $81 \%$ and $91 \%$ and for standard diclofenac it was $56 \%$ and $94 \%$ respectively. It was thus depicted that analgesic activity of test drug was significantly more than the standard in early phase and equivalent to standard in late phase.

Conclusions: It was concluded that Thespesea populnea bark extract at a dose of $10 \mathrm{mg} / \mathrm{kg}$ showed potential peripheral and central analgesic activity.
\end{abstract}

Keywords: Pain, Analgesic, Thespesea populnea, bark extract

\section{INTRODUCTION}

International association for the study of pain defines pain as "an unpleasant sensory and emotional experience associated with actual or potential tissue damage, or described in terms of such damage". ${ }^{\text {Pain }}$ is a very common localized or generalized unpleasant bodily sensation associated with actual or potential tissue damage; pain is induced by a noxious stimulus and received by naked nerve endings. ${ }^{2}$ Pain causes mild to severe physical discomfort such as pricking, throbbing and typically leads to evasive action and emotional distress.
Perception of pain is transmitted to multiple cortical areas of the brain primarily by nociceptors. ${ }^{3}$ The pain receptors are usually free nerve endings that are widespread in the superficial layers of the skin as well as in certain internal tissues such as periosteim, arterial walls, joint surfaces and cranial vault. ${ }^{3,4}$ Activation of nociceptor nerves ocuurs due to thermal/mechanical/chemical stimulus, direct trauma or through release of mediators like bradykinins, prostaglandins, histamine, serotonin arachidonic acid, etc. from damaged tissues, initiates pain sensation. ${ }^{5}$ Amount of mediators released, number of pain receptors stimulated and duration of stimulus defines the severity of pain. Myelinated A-delta type of nociceptor nerves are 
responsible or rapid transmission of pain signal and are responsible for sharp pain sensation later changing to burning sensation or soreness. ${ }^{6}$ Unmyelinated $C$ type of nociceptor nerves transmits pain sensation slowly and is associated with deep aching or throbbing types of pain that follows the initial sharp pain., ${ }^{5,6}$ Pain can be broadly classified as acute or chronic, or based on the origin of the injury or pain fibers as somatic or visceral nociceptive pain and neuropathic or sympathetic non nociceptive pain. ${ }^{?}$ Somatic pain involves nociceptors originating in the peripheral tissues such as skin and muscles, while visceral pain originates in internal organs. ${ }^{7}$ Visceral pain area is not well localized and frequently the pain sensation is referred to another area of the body. ${ }^{7,8}$ Neuropathic pain occurs due to damage of peripheral nerve anywhere in the central nervous system, persistent or paroxysmal sharp pain is sensed along the distribution of that nerve even in the absence of a painful stimulus. ${ }^{9}$

A wide range of treatment modalities are used for pain management like opoids (e.g. fentanyl, oxycodone, morphine), non-steroidal anti-inflammatory drugs (e.g. acetaminophen, ibuprofen), analgesics (e.g. paracetamol, aspirin, capsaicin cream), topical and local anesthetics (e.g. lignocaine) and non-pharmacological treatments (e.g. psychotherapy or counseling), but multimodal treatment is considered as most beneficial in pain relief due to additive or synergistic effect of different modalities and the potential to reduce side effects of an individual treatment strategy. ${ }^{10-12}$ Majority of existing treatment modalities for pain management exhibits several side effects like nausea, vomiting, skin rashes, liver damage, heart burn, upset stomach, dizziness, ringing in ears, heart/kidney failure, drowsiness, confusion, constipation etc., when taken in high or frequent dosing. ${ }^{13-15}$ So current investigation was aimed towards finding a natural origin based novel treatment modality for pain management.

Thespesia populnea a genus of malvaceae, commonly known as papal/pipalo in local Indian languages is a large tree found in tropical and coastal forests of India (Figure 1). ${ }^{17}$ Milo, Hibiscus populnea, Pacific rosewood, bebaru/baru baru are other synonyms used for Thespesia populnea, it is a common plant of coastal strands across world tropics. Thespesia populnea is a mangrove associate and plants provide shelter and food to many creatures of the mangroves. ${ }^{18}$ Thespesia populnea is an evergreen tree which is bushy when young but thins out upon aging; it grows rapidly under favorable conditions up to a height of

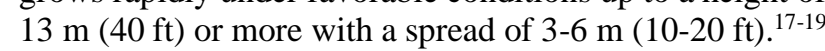
Bark of Thespesia populnea is brown, corrugated and have scaly twigs, leaves are shiny green and heart-shaped, usually ranging in size from 10 to $20 \mathrm{~cm}$ long and $6-13 \mathrm{~cm}$ broad. Cup-shaped hibiscus like pale yellow flowers (4 to $7 \mathrm{~cm}$ ) with a dark blotch at the base of the petals that last for one to two days are seen on Thespesia populnea. ${ }^{18}$ The flowers open close on same day, and the yellow flower turn dark red/purple as the day progresses. Fruits and seeds of Thespesia populnea includes a flattened indehiscent leathery sphere like capsules with disc like sepals that are green at first but turn brown and then black upon ripening and drying. The capsule usually has $8-15$ grayish brown to black seeds that are 0.7 to $1.2 \mathrm{~cm}$ long. ${ }^{17-19}$ Phytochemical investigations indicated that the ethanolic extract of Thespesia populnea bark contains alkaloids, carbohydrates, protein, tannins, phenols, flavonoids, gums and mucilage, saponins and terpenes. Gossypol was found to be the major component of Thespesia populnea; four naturally occurring quinines viz. thespone, mansonone-d, mansonone- $\mathrm{H}$, thespone and thespesone have also been found in the extracts of heartwood of Thespesia populnea. ${ }^{17-19}$

Thespesia populnea has a wide range of uses ranging from medicinal uses to food plant to timber for crafts like utensils, containers and other carved objects. The plant is used as a shade tree and windbreak and also for producing ropes and dye. ${ }^{17,18}$ Medicinally Thespesia populnea is reported to have anti-bacterial and anti-fungal properties and is useful in treating cutaneous infections, such as scabies, psoriasis, eczema, ringworm and guinea worm. Decoction of Thespesia populnea bark is commonly used for the treatment of skin and liver diseases and oil of bark mixed with vegetable oil is useful in treatment of urethritis and gonorrhea. The astringent activity found in bark, roots and fruits is used in dysentery, cholera, hemorrhoids and to heal wounds. The leaves of Thespesia populnea are reported to be anti-inflammatory, antinociceptive and are used in treating swollen joints. In addition published literature reports several other pharmacological activities like anti-oxidant, anti-fertility, anti-implantation, antisteroidogenic, anti-hyperglycemic and anti-diarrhoeal activities of extracts from different plant parts of Thespesia populnea. ${ }^{20-27}$

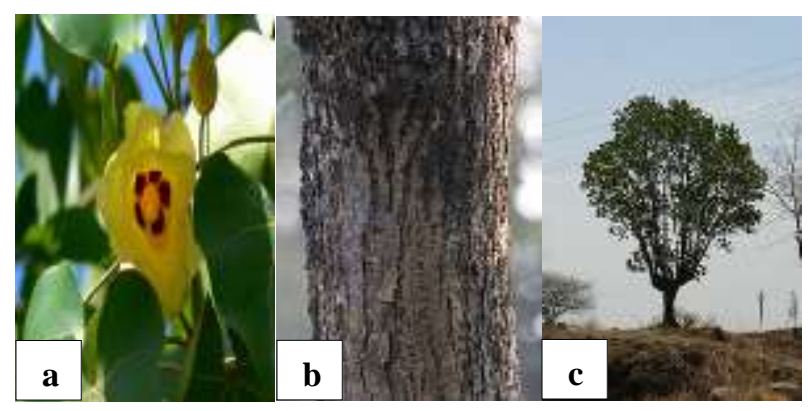

Figure 1: Thespesia populnea tree (a) aerial part, (b) whole tree and (c) bark.

\section{Aim and objectives}

Majority of existing treatment modalities for pain management exhibits several side effects, thus the aim of the present study was to determine the analgesic activity of stem bark extract of Thespesea populnea for pain management. The specific objectives of current study were to assess analgesic activity of the bark extract of Thespesea populnea using hot plate induced paw withdrawal reaction in mice, acetic acid induced writhing in mice and formalin induced paw licking in mice. 


\section{METHODS}

Current investigation was conducted at department of pharmacology, PES institute of medical sciences and research, Kuppam.

\section{Inclusion and exclusion criteria}

Animals of either sex, weighing between 20-25 grams and animals exhibiting basal reaction time less than 10 seconds were included in the study. Animals weighing less than 20 grams or more than 30 grams and showing basal reaction time more than 10 seconds were excluded from the study.

\section{Procedure}

In current study Swiss albino mice of either sex weighing 20-25 g were selected and maintained for 7 days in the animal house under standard conditions of temperature $\left(24 \pm 1^{\circ} \mathrm{C}\right)$, relative humidity $(45-55 \%)$ and $12: 12$ light: dark cycle. The animals were fed with standard rat pellets and water ad libitum and were allowed to acclimatize to laboratory conditions 48 hours prior to commencing the experiment. Animals were subjected to model experiments like hot plate induced paw withdrawal test, acetic acid induced writhing test and formalin induced paw licking test to determine the analgesic activity of the bark extract of Thespesea populnea. For each test thirty mice weighing between 20-25 g were randomly divided into 5 groups; each group consisting of 6 animals, control group in all the tests were orally given $2 \%$ gum acacia, standard group in hot plate induced paw withdrawal test received pentazocine, intraperitoneally $(25 \mathrm{mg} / \mathrm{kg})$, for acetic acid induced writhing test and formalin induced paw licking test, the standard groups were orally given diclofenac sodium $(10 \mathrm{mg} / \mathrm{kg})$.

In all the experiments, test groups 1, 2 and 3 were orally given $3 \mathrm{mg} / \mathrm{kg}, 10 \mathrm{mg} / \mathrm{kg}$ and $30 \mathrm{mg} / \mathrm{kg}$ of bark extract Thespesea populnea respectively after suspending the extract in $2 \%$ gum acacia solution.

\section{Hot plate induced paw withdrawal test}

Eddy's hot plate was maintained at temperature of $55 \pm 1^{\circ} \mathrm{C}$ and the paw of mice was placed on the preheated hot plate, since the paw of mouse is very sensitive to heat at temperatures which are not skin damaging, latency time for responses like jumping, withdrawal of the paw from the hot plate or licking of the paw at the above mentioned temperature were recorded with the aid of a stop watch.

Time for the responses was expected to prolong after administration of centrally acting analgesics, whereas peripheral analgesics do not generally affect these responses. Observations were made at the time intervals of 60, 120 and 180 minutes following administration of the standard and the test compound with the cut off time of 15 seconds.

\section{Acetic acid induced writhing test}

Acetic acid induce pain when given through injection into the peritoneal cavity of mice and the animals start reacting with a characteristic stretching behavior called as writhing. After one hour of drug administration all the animals including the test and standard groups were intraperitoneally injected with acetic acid $(0.1 \mathrm{ml} / 10 \mathrm{~g})$. Five minutes after the injection response of the animals in form of number of writhes was counted in individual mice for a period of 20 minutes. Numbers of writhes were expected to be reduced in groups administered with analgesics incomparision to control group. Percent protection against acetic acid induced writhing was calculated using the formula;

standard - control/control $\times 100$

\section{Formalin induced paw licking test}

In current study, formalin test has been proposed as a chronic pain model which is sensitive to both peripherally and centrally active analgesics. Pain responses in this model were indicated by elevation or favouring of the paw or excessive licking and biting of the paw. One hour post drug administration in standard and test groups, each mouse was subcutaneously given $0.1 \mathrm{ml}$ of $1 \%$ formalin under the dorsal surface of the hind paw and was observed for licking response after 0-10 minutes and 20-30 minutes. Analgesics were expected to be effective if both paws of mice rested on the floor with no obvious favouring of the injected paw. Percent protection against formalin induced paw licking in mice was calculated using the formula;

standard - control/control $\times 100$

\section{Statistical analysis}

All the collected and observed data were statistically analyzed using ANOVA test followed by Dunnett's test.

\section{RESULTS}

\section{Hot plate induced paw withdrawal test}

Pre-clinical observations made at time intervals of 60,120 and 180 minutes post administration of the standard and test analgesic compounds in terms of licking of paw by mice in hot plate model are revealed in (Table 1). Latency time for licking response post 60 minutes in control and standard groups were observed to be $7.4 \pm 0.89$ seconds and $12.33 \pm 0.71$ seconds respectively. Paw licking latency time in the test group orally treated with $3 \mathrm{mg} / \mathrm{kg}, 10 \mathrm{mg} / \mathrm{kg}$ and $30 \mathrm{mg} / \mathrm{kg}$ of bark extract Thespesea populnea were observed to be $7.00 \pm 0.5$ seconds, $8.2 \pm 0.93$ seconds and $8.6 \pm 1.70$ seconds respectively post 60 minutes of extract administration. The overall all percent increase in paw licking latency time in standard and test groups when compared to control group are shown in (Figure 1). Similarly, latency time and percent increase in latency time 
for paw licking response in mice post 120 and 180 minutes, in control, standard and test groups are depicted in (Table 1 and Figure 2). It was observed from the results of the investigations that the test extract of Thespesea populnea at $10 \mathrm{mg} / \mathrm{kg}$ concentration attained peak effect at 180 minutes and the effect declined at 60 minutes, whereas pentazocine treated group attained peak effect at 180 minutes.

Table 1: Latency time for paw licking response in mice observed in hot plate method.

\begin{tabular}{|c|c|c|c|}
\hline \multirow{2}{*}{$\begin{array}{l}\text { Treatment } \\
\text { groups }\end{array}$} & \multicolumn{3}{|c|}{$\begin{array}{l}\text { Latency time (seconds) of paw } \\
\text { licking response observed at post } \\
\text { treatment time intervals }\end{array}$} \\
\hline & $\begin{array}{l}60 \\
\text { minutes }\end{array}$ & $\begin{array}{l}120 \\
\text { minutes }\end{array}$ & $\begin{array}{l}180 \\
\text { minutes }\end{array}$ \\
\hline Control & $7.4 \pm 0.89$ & $7.8 \pm 0.67$ & $6.00 \pm 0.5$ \\
\hline $\begin{array}{l}\text { Standard } \\
\text { (Pentazocine; } \\
\text { 25mg/kg) }\end{array}$ & $12.33 \pm 0.71$ & $\begin{array}{l}11.67 \pm 1 . \\
31\end{array}$ & $\begin{array}{l}13.5 \pm 0.5 \\
6 * *\end{array}$ \\
\hline $\begin{array}{l}\text { Test group } 1 \\
\text { (TP bark extract, } \\
3 \mathrm{mg} / \mathrm{kg} \text { ) }\end{array}$ & $7.00 \pm 0.5$ & $\begin{array}{l}10.2 \pm 0.7 \\
3\end{array}$ & $\begin{array}{l}11.4 \pm 0.9 \\
8 * *\end{array}$ \\
\hline $\begin{array}{l}\text { Test group } 2 \\
\text { (TP bark extract, } \\
10 \mathrm{mg} / \mathrm{kg} \text { ) }\end{array}$ & $8.2 \pm 0.93$ & $\begin{array}{l}13.2 \pm 0.6 \\
7 * *\end{array}$ & $\begin{array}{l}14.2 \pm 0.5 \\
3 * *\end{array}$ \\
\hline $\begin{array}{l}\text { Test group } 3 \\
\text { (TP bark extract, } \\
30 \mathrm{mg} / \mathrm{kg} \text { ) }\end{array}$ & $8.6 \pm 1.70$ & $\begin{array}{l}10.8 \pm 1.4 \\
8\end{array}$ & $\begin{array}{l}11.4 \pm 1.4 \\
3 * *\end{array}$ \\
\hline
\end{tabular}

TP-Thespesea populne, values are expressed as mean \pm SEM, ${ }^{*} \mathrm{p}<0.01$ compared with control group using one-way ANOVA followed by Dunnett's test.

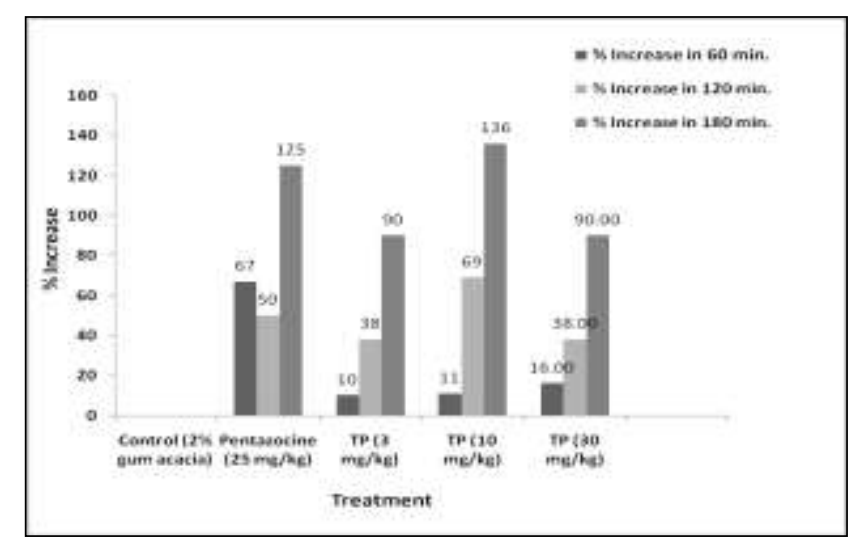

TP-Thespesea populne

Figure 2: Percent increase in latency time of standard and test groups in comparison to control group for paw licking response in mice using hot plat method.

\section{Acetic acid induced writhing test}

Preclinical observations made in the form of numbers of writhing in 20 minutes using acetic acid induced writhing model are depicted in (Table 2). Percent increase in writhing inhibition in standard and test groups post treatment in comparison to the control group is depicted in (Table 2 and Figure 3). It was observed through the current study findings that pre-treatment with diclofenac $(10 \mathrm{mg} / \mathrm{kg})$ and bark extract of Thespesea populnea $(3 / 10 / 30 \mathrm{mg} / \mathrm{kg})$ significantly inhibited acetic acid induced writhing behaviour in mice. It was observed that extract of Thespesea populnea produced dose dependent inhibition in writhing behaviour. The results suggests that extract of Thespesea populnea possess significant analgesic activity against acetic acid induced pain, however its potency was found to be lesser than diclofenac sodium.

Table 2: Number of writhing and percentage inhibition in writhing response observed in mice up to 20 minutes using acetic acid induced writhing model.

\begin{tabular}{|lll|}
\hline & $\begin{array}{l}\text { Number of } \\
\text { writhing } \\
\text { (counts/20 } \\
\text { minutes) }\end{array}$ & $\begin{array}{l}\text { Percent } \\
\text { inhibition }\end{array}$ \\
\hline Control & $69.5 \pm 6.75$ & -- \\
\hline $\begin{array}{l}\text { Standard } \\
\text { (Pentazocine; 25mg/kg) }\end{array}$ & $13.33 \pm 2.24 * *$ & 80.81 \\
\hline $\begin{array}{l}\text { Test group 1 } \\
\text { (TP bark extract, 3 } \\
\text { mg/kg) }\end{array}$ & $41.5 \pm 8.32^{* *}$ & 40.29 \\
\hline $\begin{array}{l}\text { Test group 2 } \\
\text { (TP bark extract, 10 } \\
\text { mg/kg) }\end{array}$ & $33.83 \pm 4.17 * *$ & 51.32 \\
\hline $\begin{array}{l}\text { Test group 3 } \\
\text { (TP bark extract, 30 } \\
\text { mg/kg) }\end{array}$ & $22.17 \pm 3.89 * *$ & 68.10 \\
\hline
\end{tabular}

Values are expressed as mean \pm SEM, $* * \mathrm{p}<0.01$ compared with control group using one way ANOVA followed by Dunnett's test.

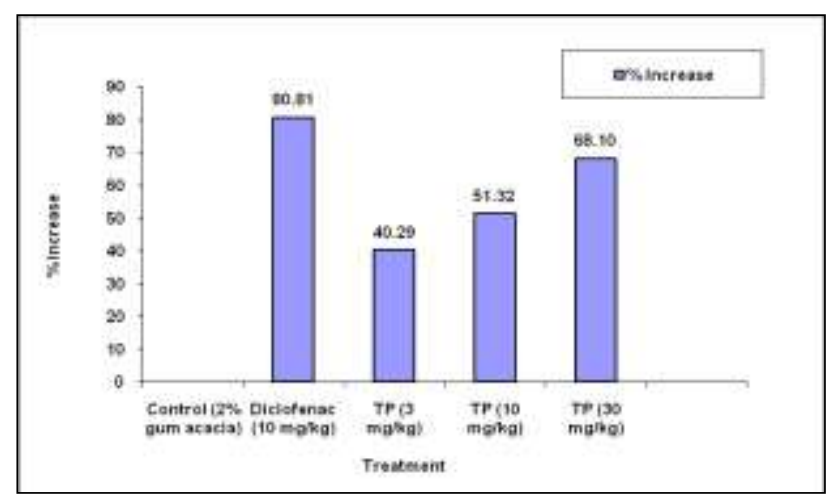

Figure 3: Percent inhibition in writhing response observed up to 20 minutes in standard and test groups compared to control group using acetic acid induced writhing model.

\section{Formalin induced paw licking test}

Preclinical observations made in the form of numbers of lickings made by mice in early phase (0-10 minutes) and late phase (20-30 minutes) using formalin induced paw 
licking test are depicted in (Table 3). Percent increase in licking inhibition in both early and late phases in standard and test groups post treatment compared to the control group is depicted in (Figure 4-5).

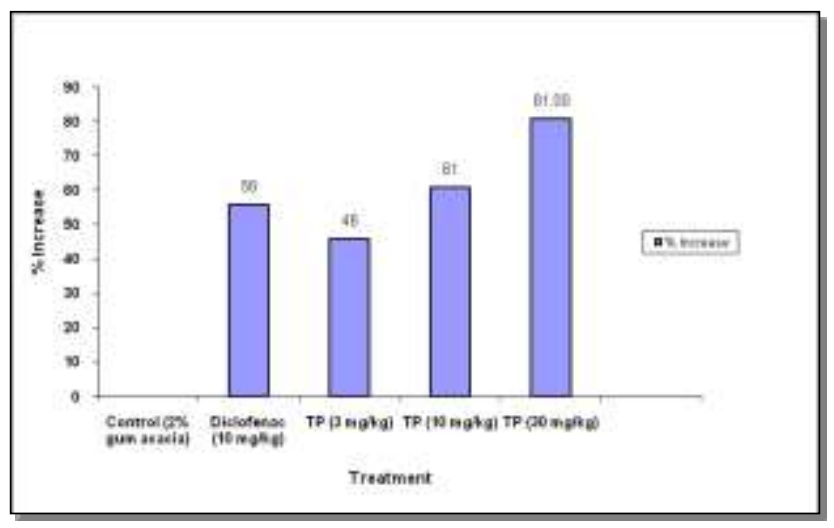

Figure 4: Early phase percent inhibition in licking response in standard and test groups compared to control group using formalin induced paw licking model.

Results of the current study findings depicted that pretreatment with diclofenac $(10 \mathrm{mg} / \mathrm{kg})$ and bark extract of
Thespesea populnea (3/10/30 $\mathrm{mg} / \mathrm{kg}) \quad$ significantly inhibited formalin induced paw licking behaviour in mice. It was observed that extract of Thespesea populnea produced dose dependent inhibition in paw licking behaviour. The results suggest that extract of Thespesea populnea possess significant analgesic activity against formalin induced pain in mice.

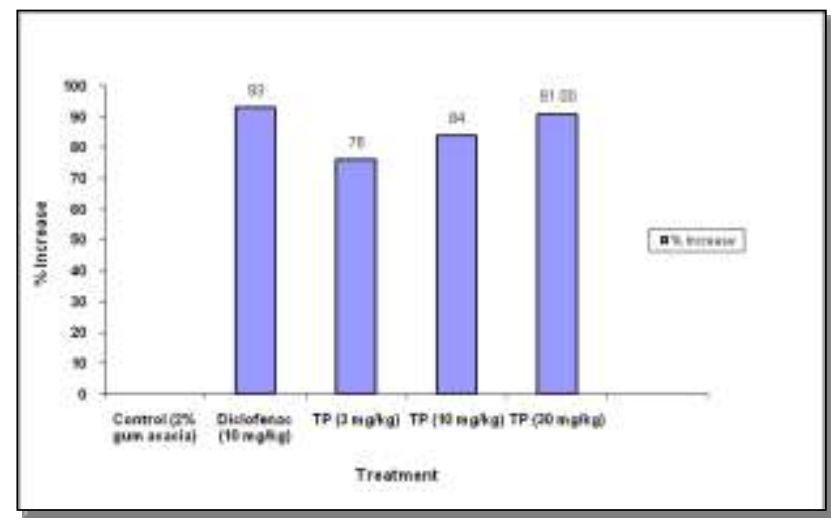

Figure 5: Late phase percent inhibition in licking response in standard and test groups compared to control group using formalin induced paw licking model.

Table 3: Number of paw lickings and percentage inhibition in licking response observed in treated mice using formalin induced paw licking model.

\begin{tabular}{|c|c|c|c|c|}
\hline \multirow[b]{2}{*}{ Treatment groups } & \multicolumn{2}{|c|}{ Number of lickings } & \multicolumn{2}{|c|}{ Percentage inhibition } \\
\hline & $\begin{array}{l}\text { Early phase } \\
(0-10 \text { minutes })\end{array}$ & $\begin{array}{l}\text { Late phase } \\
\text { (20-30 minutes) }\end{array}$ & $\begin{array}{l}\text { Early phase } \\
(0-10 \text { minutes })\end{array}$ & $\begin{array}{l}\text { Late phase } \\
(20-30 \text { minutes })\end{array}$ \\
\hline Control & $107 \pm 15.52$ & $77.4 \pm 5.35$ & -- & -- \\
\hline $\begin{array}{l}\text { Standard } \\
\text { (Pentazocine; 25mg/kg) }\end{array}$ & $46.7 \pm 3.14 * *$ & $4.67 \pm 0.67 * * *$ & 56.39 & 93.97 \\
\hline $\begin{array}{l}\text { Test group } 1 \\
\text { (TP bark extract, } 3 \text { mg/kg) }\end{array}$ & $57.5 \pm 0.67 * * *$ & $18.5 \pm 1.45^{* * *}$ & 46.26 & 76.10 \\
\hline $\begin{array}{l}\text { Test group } 2 \\
\text { (TP bark extract, } 10 \mathrm{mg} / \mathrm{kg} \text { ) }\end{array}$ & $40.83 \pm 1.72 * * *$ & $12 \pm 1.07 * * *$ & 61.84 & 84.50 \\
\hline $\begin{array}{l}\text { Test group } 3 \\
\text { (TP bark extract, } 30 \mathrm{mg} / \mathrm{kg} \text { ) }\end{array}$ & $19.67 \pm 1.38 * * *$ & $6.83 \pm 1.14 * * *$ & 81.68 & 91.17 \\
\hline
\end{tabular}

Values are expressed as mean \pm SEM, $* * \mathrm{p}<0.01, * * * \mathrm{p}<0.001$ compared with control group using one-way ANOVA followed by Dunnett's test

\section{DISCUSSION}

Results of current investigation revealed that bark extract of Thespesea populnea exhibited dose dependent analgesic activity, which was confirmed through preclinical hot plate induced paw withdrawal test model, acetic acid induced writhing test model and formalin induced paw licking test model. Observation made from hot plate induced paw withdrawal model revealed that no significant change in response of animals was observed over a period of three hours. The percent increase in reflex latency of the paw licking response in mice for standard drug pentazocin at a dose of $25 \mathrm{mg} / \mathrm{kg}$ was observed to be at peak after 180 minutes. The intensity of analgesic activity of the
Thespesea populnea extract was observed to be dose dependent. It is observed that the test drug at concentration of $10 \mathrm{mg} / \mathrm{kg}$ attained peak effect of $136 \%$ at 180 minutes, whereas standard drug pentazocine attained peak effect of $125 \%$ at 180 minutes. Observations thus revealed that bark extract of Thespesea populnea produced more analgesia compared to pentazocine. Since the classical hot plate model is reported to be suitable for measuring anti nociceptive effects of centrally acting analgesics, thus it can be conceived that analgesic effect of Thespesea populnea bark extract, is centrally acting. ${ }^{28}$ Results of acetic acid induced writhing model revealed that in test group animals treated with Thespesea populnea bark extract number of writhings produced by acetic acid were significantly reduced by $40 \%$ at $3 \mathrm{mg} / \mathrm{kg}$ dose, $51 \%$ at 
$10 \mathrm{mg} / \mathrm{kg}$ dose and $68 \%$ at $30 \mathrm{mg} / \mathrm{kg}$ dose compared to $80 \%$ reduction observed in $10 \mathrm{mg} / \mathrm{kg}$ of standard diclofenac solution. Acetic acid causes inflammatory pain by inducing capillary permeability and liberating endogenous substances that excite pain in nerve endings, NSAIDs inhibit cyclooxygenase in peripheral tissues and, therefore, interfere with the mechanism of transduction of primary afferent nociceptors. ${ }^{29}$ Hence it can be perceived that Thespesea populnea bark extract may reduce writhing by inhibiting the release of endogenous substance, responsible for pain indicating that Thespesea populnea bark extract can also exhibit peripheral analgesic effect. Observations made from formalin induced paw licking model revealed that in early phase inflammatory pain (10 minutes immediately after the formalin injection) Thespesea populnea bark extract, at a dose of $30 \mathrm{mg} / \mathrm{kg}$ showed more efficacy compared to the standard drug diclofenac $(10 \mathrm{mg} / \mathrm{kg})$ in inhibiting the licking response, whereas in late phase (approximately 20 minutes after formalin injection) Thespesea populnea bark extract, at a dose of $30 \mathrm{mg} / \mathrm{kg}$ was observed to be almost equally effective $(91 \%)$ compared to the standard drug diclofenac $(93 \%)$ at a dose of $10 \mathrm{mg} / \mathrm{kg}$. Pain in early phase is caused by $\mathrm{C}$-fibre activation due to the peripheral stimulus inducing neurogenic pain. In late phase, pain appears to depend on the inflammatory reaction; in the peripheral tissue and functional changes in the dorsal horn of the spinal cord. ${ }^{30}$ Thus the results indicated that Thespesea populnea bark extract can also inhibit supraspinal and spinal mediated neurogenic pain and peripherally mediated inflammatory pain.

\section{Limitations}

Limitations of current study were; the test substance in present investigation is from natural origin which is vastly biodiverse, this limitation can be addressed by standardization of the Thespesea populnea bark extract using officially reported techniques. The results and conclusion would have been more specific if the active constituent responsible for analgesic activity in Thespesea populnea bark extract could have been isolated and investigated.

\section{CONCLUSION}

It can be concluded from current study findings that Thespesea populnea bark extract exhibited good analgesic activity through all the three testing models. The extract at a dose of $10 \mathrm{mg} / \mathrm{kg}$ exhibited significant analgesia compared to the standard, pentazocine used in hot plate induced paw withdrawal model. The analgesic activity of extract was found to less compared to the standard, diclofenac sodium used in acetic acid induced writhing model, whereas in the early and late phase of formalin induced paw licking model, extract was observed to be having greater and equivalent analgesic response compared to diclofenac sodium respectively. Thus it can be overall concluded from the present the investigation that Thespesea populnea bark extract induces analgesia both peripherally and centrally and can inhibit supraspinal and spinal mediated neurogenic pain and peripherally mediated inflammatory pain.

Funding: No funding sources

Conflict of interest: None declared

Ethical approval: The study was approved by the Institutional Ethics Committee

\section{REFERENCES}

1. Loeser JD, Treede RD. The kyoto protocol of IASP basic pain terminology. Pain. 2008;137(3):473-7.

2. Merskey HM. Pain terms. Pain. 1986;3:S215-21.

3. Raffaeli W, Arnaudo E. Pain as a disease: an overview. J Pain Res. 2017;10:2003-8.

4. Byers M, Bonica JJ. Peripheral neural mechanisms of nociceptor plasticity. In: Loeser JD, Butler SH, Chapman CR, Turk DC, eds. Bonica's Management of Pain. Philadelphia: Lippincott Williams \& Wilkins; 2001:26-72.

5. Schaible HG. Peripheral and central mechanisms of pain generation. Handb Exp Pharmacol. 2007;177:328.

6. Truini A, Cruccu G. Pathophysiological mechanisms of neuropathic pain. Neurol Sci. 2006;27 (Suppl 2):S179-82.

7. Kumar SP, Saha S. Mechanism-based Classification of Pain for Physical Therapy Management in Palliative care: A Clinical Commentary. Indian J Palliat Care. 2011;17(1):80-6.

8. Devor M. Pain mechanisms. Neuroscientist. 1996;2:233-44.

9. Smart K, Doody C. Mechanism-based clinical reasoning of pain by experienced musculoskeletal physiotherapists. Physiotherapy. 2006;92:171-8.

10. Ripamonti CI. Pain management. Ann Oncol. 2012;23 (Suppl 10):294-301.

11. Chou R, Gordon DB, de Leon-Casasola OA. Management of postoperative pain: a clinical practice guideline from the American pain society, the American society of regional anesthesia and pain medicine, and the American society of anesthesiologists' committee on regional anesthesia, executive committee, and administrative council. $J$ Pain. 2016;17(2):131-57.

12. Nalamachu S. An overview of pain management: the clinical efficacy and value of treatment. Am J Manag Care. 2013;19(Suppl 14):s261-6.

13. Thomas MA. Pain management - the challenge. Ochsner J. 2003;5(2):15-21.

14. Varrassi G, Müller-Schwefe G, Pergolizzi J, Orónska A, Morlion B, Mavrocordatos $\mathrm{P}$, et al. Pharmacological treatment of chronic pain - the need for CHANGE. Curr Med Res Opin. 2010;26:1231-45.

15. Roelofs PD, Deyo RA, Koes BW, Scholten RJ, van Tulder MW. Nonsteroidal anti-inflammatory drugs for low back pain: an updated Cochrane review. Spine. 2008;33:1766-74. 
16. Kiritikar KR, Basu BD. Indian medicinal plants. In: Blaster E, Caius JF, Bhaskar KS, eds. New Delhi: Periodical Experts Book Agency; 1991.

17. Thespesia populnea. Available at: http://www.hibiscus.org/species/tpopulnea.php. Accessed on 20 November 2020.

18. Thespesia populnea. Available at:https://www.docdeveloppement-durable.org/file/Arbres-Bois-deRapport-Reforestation/FICHES_ARBRES/Arbresnon-classes/Thespesia-milo.pdf. Accessed on 20 November 2020.

19. Corner EJH. Wayside Trees of Malaya. 4th ed. Kuala Lumpur: Malayan Nature Society; 1997.

20. Nagappa AN, Cheriyan B. Wound healing activity of the aqueous extract of Thespesia populnea fruit. Fitoterapia. 2001;72(5):503-6.

21. Krishnamoorthy P, Vaithinathan S. Effect of the extract of Thespesia populnea leaves on mice testis. J Environ Biol. 2003;24(3):327-30.

22. Yuvaraj P, Subramoniam A. Hepatoprotective property of Thespesia populnea against carbon tetrachloride induced liver damage in rats. J Basic Clin Physiol Pharmacol. 2009;20(2):169-77.

23. Belhekar SN, Chaudhari PD, Saryawanshi JS, Mali KK, Pandhare RB. Antidiabetic and antihyperlipidemic effects of Thespesia populnea fruit pulp extracts on alloxan-induced diabetic rats. Indian J Pharm Sci. 2013;75(2):217-21.

24. Rangani J, Kumari A, Patel M, Brahmbhatt H, Parida AK. Phytochemical profiling, polyphenol composition, and antioxidant activity of the leaf extract from the medicinal halophyte Thespesia populnea reveal a potential source of bioactive compounds and nutraceuticals. J Food Biochem. 2019;43(2):e12731.

25. Ilavarasan $R$, Vasudevan $M$, Anbazhagan S, Venkataraman S. Antioxidant activity of Thespesia populnea bark extracts against carbon tetrachlorideinduced liver injury in rats. $\mathbf{J}$ Ethnopharmacol. 2003;87(2-3):227-30.

26. iswanatha GL, Hanumanthappa S, Krishnadas N, Rangappa S. Antidiarrheal effect of fractions from stem bark of Thespesia populnea in rodents: Possible antimotility and antisecretory mechanisms. Asian Pac J Trop Med. 2011;4(6):451-6.

27. Vasudevan M, Parle M. Pharmacological actions of Thespesia populnea relevant to Alzheimer's disease. Phytomedicine. 2006;13(9-10):677-87.

28. Menéndez L, Lastra A, Hidalgo A, Baamonde A. Unilateral hot plate test: a simple and sensitive method for detecting central and peripheral hyperalgesia in mice. J Neurosci Methods. 2002;113(1):91-7.

29. Gawade SP. Acetic acid induced painful endogenous infliction in writhing test on mice. J Pharmacol Pharmacother. 2012;3(4):348.

30. Hunskaar S, Hole K. The formalin test in mice: dissociation between inflammatory and noninflammatory pain. Pain. 1987;30(1):103-14.

Cite this article as: Jayakumar JK. Pharmacological investigation of Thespesea populnea bark extract for analgesic activity. Int $\mathrm{J}$ Basic Clin Pharmacol 2021;10:115-21. 